\title{
Faecal coliforms, faecal enterococci, Salmonella Typhi and Acanthamoeba spp. UV inactivation in three different biological effluents
}

\author{
NA Beltrán ${ }^{1 *}$ and BE Jiménez ${ }^{2}$ \\ ${ }^{1}$ Instituto de Investigaciones Eléctricas. Calle Reforma 13. Col. Palmira, C.P. 62490, Cuernavaca Morelos. México \\ 2Instituto de Ingeniería, UNAM. Apdo. Postal 70472; Ciudad Universitaria, Delegación Coyoacán, C.P. 04510, D.F. México
}

\begin{abstract}
Efficiency of UV-light to inactivate microbial indicators, Salmonella Typhi and Acanthamoeba spp. was studied in three different biological secondary effluents. Even though effluents differed in terms of their total suspended solids content, transmittance and particle size distribution, the UV-light dose required to fulfil WHO agricultural water reuse criteria was the same $\left(30 \mathrm{~mW} \cdot \mathrm{s} / \mathrm{cm}^{2}\right)$, because the particle content with sizes $>40 \mu \mathrm{m}$ was similar and very small. Using this dosage, $3 \log$ of Salmonella Typhi and faecal enterococci were also inactivated. To avoid faecal coliform and Salmonella Typhi photoreactivation, the UV dose had to be doubled and in the process $2.5 \log$ of Acanthamoeba spp. were also inactivated. This is interesting because its presence in wastewater, pathogenicity and resistance to conventional disinfection processes has been reported in the literature. Additionally, it was found that the faecal coliforms' inactivation rate constant was the lowest one of all the bacteria studied (Salmonella Typhi and faecal enterococci), suggesting the limitation of this indicator when several kinds of pathogens are present, as is the case in developing countries.
\end{abstract}

Keywords: amoebae, UV disinfection, indicators, pathogen, risks assessment, wastewater

\section{Introduction}

In 2001, water-borne diarrheic diseases represented $13 \%$ of the 15 million deaths caused by all types of infectious diseases worldwide, $74 \%$ occurring in children under the age of 5 in the developing world (Hinrichsen and Robey, 2000). One of the main causes of diarrhoea is the consumption of crops irrigated with polluted water. It is estimated that at least $20 \times 10^{6}$ ha in 50 countries are irrigated using wastewater and that $10 \%$ of the crops consumed in the world are produced this way, although for some countries, such as Thailand, consumption may be as high as 90\% (Carr et al., 2004; Scott et al., 2004). There are no estimates of the amount of crops produced using polluted water but it is reasonable to assume that the figures could be much higher than those presented for wastewater. This is of particular concern for developing countries because, on the one hand, higher concentrations of a wider variety of organisms (bacteria, viruses, protozoa, and helminth ova) are present in wastewater compared to developed countries' wastewater (Jiménez et al., 2001), and on the other hand, it is frequently cited in the literature that the behaviour of pathogens during disinfection is not properly modelled by common microbial indicators (Chang et al., 1985; Ashbolt et al., 2001).

Salmonella Typhi is one such pathogen usually present in wastewater produced in developing countries and in high concentrations. This bacterium is responsible for typhoid fever, a disease transmitted through the ingestion of polluted water or food which is very common worldwide. It is estimated that

\footnotetext{
* To whom all correspondence should be addressed.

獣 +52(777)362-3811; fax: +52(777)362-3832;

e-mail: nbeltran@iie.org.mx

Received 31 July 2007; accepted in revised form 29 January 2008.
}

12.5 million people worldwide are infected annually. In Mexico alone, 7481 cases of typhoid fever were reported in 2002; by comparison, there were 400 cases in the United States, 200 in the UK and 90 in France (WHO, 1998; CDC, 2001).

Protozoa are another group of micro-organisms contained in wastewater. The pathogenic enteric protozoa compromise the health of millions of people and contribute significantly to diarrhoeal disease morbidity. Their prevalence varies between 2 and $5 \%$ in developed countries while in developing ones it is 20 and $30 \%$ (Norhayati et al., 2003). It is currently perceived that Cryptosporidium (mainly) and Giardia (occasionally) are the only emerging protozoan pathogens, but there are many others in wastewater, depending on the local health situation. One example is Acanthamoeba spp. which is a non-faecal pathogenic protozoan found in a variety of environments and isolated from wastewater used to irrigate crops in Mexico (Maya, 2000). Its mode of infection is believed to be via skin lesions or through the respiratory tract rather than oral ingestion, occurring mainly in immuno-compromised individuals or young children. It can cause diseases in farmers if they come in direct contact with wastewater, as frequently happens in areas where non-treated wastewater is used for irrigation and in the general population when sprinkler irrigation is used or when children play in the open canals transporting wastewater. Moreover, wastewater and polluted soil have been described as pathogen reservoirs that pollute crops during cultivation by splashing or through windblown dust or by direct contact with fruits. Although rare, Acanthamoeba infections can cause death, as has been reported in the USA, Australia and Europe, which are countries with enough institutional capacity to track down the disease (Dreelin, 2005).

The sanitary importance of Acanthamoeba resides in its pathogenicity and resistance to conventional disinfection processes (Martínez and Visvevara, 1997). UV-light disinfection is an efficient method for inactivating bacteria, viruses and some 


\begin{tabular}{|l|l|l|}
\hline \multicolumn{3}{|c|}{ Analytical techniques used for physical and microbiological characterisation } \\
\hline Parameter & Unit & Technique/Reference \\
\hline Total suspended solids, TSS & $\mathrm{mg} / \ell$ & Gravimetric, Standard Methods (1998), method 2540 D \\
\hline Transmittance & $\%$ & Photometric \\
\hline Filtered transmittance $(0.45 \mu \mathrm{m})$ & $\%$ & Photometric \\
\hline Particle size distribution, PSD & $\mu \mathrm{m}$ & Coulter principle, Standard Methods (1998), method 2560 B \\
\hline Faecal coliforms, FC & CFU/100 m $\ell$ & MF, Standard Methods (1998), method 9222 D \\
\hline Faecal enterococci, FE & CFU /100 m $\ell$ & MF, Standard Methods (1998), method 9230 C \\
\hline Salmonella Typhi & CFU /100 m $\ell$ & MF, Standard Methods (1998), method 9260 D \\
\hline MF: Membrane filtration & \\
\hline
\end{tabular}

protozoa without producing by-products, as is the case with chlorine (Dodds et al., 1999; Linden et al., 2002). However, its effects on Acanthamoeba have been rarely studied (Maya et al., 2003). The required UV dose for an effluent depends on the water quality, the previous treatment process and the targeted microorganisms. UV-light is considered to be an interesting option for disinfecting effluents intended for agricultural reuse because it avoids the presence of organochlorides in aquifers recharged with the wastewater excess used to irrigate. This is important because it has been reported that aquifers recharged in this way are also used as a drinking source, for instance in Mexico, Peru and Thailand (Foster et al., 2003; Jiménez and Chávez, 2004). Unfortunately, even though there is ample literature on UV-light disinfection, this technology has scarcely replaced chlorination. Most of the literature focuses on the inactivation of microbial indicators such as faecal coliforms (in most of the cases), faecal enterococci and E. coli (Jijnen et al., 2006) or other micro-organisms of interest in the developed world. Knowledge of the effect of UV-light on pathogens of interest to the developing world, such as Salmonella Typhi and Acanthamoeba spp., is poor and so it would be useful to define its possible effects on these or other similar pathogens. Considering the abovementioned facts, this research evaluated UV-light inactivation of indicators and other pathogens usually contained in wastewater intended for agricultural reuse in concentrations common for developing countries. Because UV-light disinfection efficiency depends on the quality of the effluent (Madge and Jensen, 2006), three different types of effluents from widely used biological processes were studied. The objectives were to:

- Determine the effect of the type of effluent (in terms of total suspended solids (TSS) content, transmittance and particle size distribution) on UV-light efficacy

- Analyse the effect of using a UV-light disinfection dose which fulfils WHO criteria doses for faecal enterococci, Salmonella Typhi and Acanthamoeba spp. as well as their disinfection kinetics parameters

- Evaluate the reactivation of faecal coliforms and Salmonella Typhi

- Analyse the effect of micro-organisms embedded in particles on disinfection efficiency. Additionally, the health risks caused by Salmonella Typhi on wastewater disinfected according to the WHO guidelines were determined.

\section{Experimental}

\section{Sampling}

Wastewater from a treatment plant (WWTP) located in the National Autonomous University of Mexico was selected for this study. This plant treats $40 \mathrm{l} / \mathrm{s}$ of municipal wastewater coming from the university campus and a nearby residential neighbourhood. It has three biological processes working in parallel: activated sludge, trickling filter and rotating biological contactors. The activated sludge (AS) process treats $20 \mathrm{l} / \mathrm{s}$ at a $0.3 \mathrm{~kg} \mathrm{BOD} /$ $\mathrm{m}^{3} \cdot \mathrm{d}$ load, a $5 \mathrm{~h}$ hydraulic retention time with a mean cell residence time of $5 \mathrm{~d}$. The trickling filter (TF) operates at $10 \mathrm{\ell} / \mathrm{s}$, has a hydraulic retention time of $0.6 \mathrm{~h}$, a $50 \%$ recirculation ratio and a BOD load of $0.5 \mathrm{~kg} / \mathrm{m}^{3} \cdot \mathrm{d}$. Finally, the rotating biological contactor $(\mathrm{RBC})$ has a flow of $10 \mathrm{l} / \mathrm{s}, 1 \mathrm{~h}$ hydraulic retention time, 1.6 $\mathrm{r} / \mathrm{min}$ rotational speed and operates at $10 \mathrm{gBOD} / \mathrm{m}^{2} \cdot \mathrm{d}$ load.

For the disinfection tests, $4 \ell$ of effluent were collected from the secondary clarifier of each biological process every week for 3 years at the same hour of the day and during the rainy season (May to July). The rainy season was selected as a sampling period as diarrheic morbidity rates reach their maximum values during this period, and therefore the pathogenic content in the wastewater is higher. Samples were taken in clean plastic containers and kept at $4^{\circ} \mathrm{C}$ for their immediate analysis (less than $0.5 \mathrm{~h}$ ).

\section{Effluents characterisation and irradiation tests}

The effluents were characterised physically and microbiologically following Standard Methods (1998) procedures (Table 1). The particle size distribution was determined, both in volume and in number, using the coulter principle. Particle size distribution in volume was calculated assuming that particles were spherical with a diameter equal to the logarithmic average of the particle diameters measured for each size range (Adin, 1998).

UV-light disinfection tests were carried out using a collimated-beam reactor, with a horizontally suspended low pressure mercury lamp projecting light perpendicularly to the sample surface. Each test was repeated at least 3 times, using a $50 \mathrm{~m} \ell$ continuously stirred sample ( $25 \mathrm{~mm}$ magnetic bar) in a $55 \mathrm{~mm}$ diameter sterile glass container. The mean intensity of UV-light applied was $0.22 \pm 0.02 \mathrm{~mW} / \mathrm{cm}^{2}$ and was calculated by measuring the irradiation intensity at the beginning and at the end of each experiment. Intensity was measured with an International Light Inc. Calibrated Radiometer, IL 1700 coupled with an SED240 \#4817 detector placed at the same height as the sample. The detector measured light-wave lengths of between 200 and $320 \mathrm{~nm}$. The amount of UV-light applied was estimated by subtracting the quantity absorbed by water calculated using Beer's law. The final dose applied $\left(\mathrm{mW} \cdot \mathrm{s} / \mathrm{cm}^{2}\right)$ was calculated using Eq. (1):

$$
D=I x t
$$

where:

$I=$ Intensity of UV light $\left(\mathrm{mW} / \mathrm{cm}^{2}\right)$

$t=$ Exposure time (s) 
To obtain different irradiation doses (between 5 and 120 $\mathrm{mW} \cdot \mathrm{s} / \mathrm{cm}^{2}$ ) the exposure time was varied during the experiments.

To measure the disinfection efficiency, conventional biological indicators (faecal coliforms and enterococci) were used and two specific pathogens (Salmonella Typhi and Acanthamoeba spp.) were deemed to be of interest because they are disease agents common to developing countries and are associated with the use of wastewater for irrigation, as explained earlier.

Faecal coliforms, faecal enterococci and Salmonella Typhi disinfection tests were carried out without adding bacteria strains to the wastewater, i.e., just considering the 'normal content' in the wastewater. This content resulted in 2 to 3 $\log$ orders of magnitude, higher than that found in developed countries (Jiménez et al., 2001; Tchobanoglous et al., 2003). Amoebae disinfection experiments were performed in $50 \mathrm{~m} \ell$ of filtered and sterilised activated sludge effluent inoculated with $200 \mu \ell$ of a concentrated suspension of amoebae $\left(10^{4}\right.$ cysts/m $/$ Acanthamoeba spp.). The suspension was prepared following the recommendation given by Maya et al. (2003) by inoculating the trophozoite form in an axenic culture and incubating it at $30^{\circ} \mathrm{C}$ over a period of $7 \mathrm{~d}$ to avoid culture contamination. The incubated suspension was then centrifuged at $2500 \mathrm{r} / \mathrm{min}$ for $10 \mathrm{~min}$. The Acanthamoeba spp. content in the sediment was then measured using a Neubauer chamber $0.1 \mathrm{~mm}$ in depth. The procedure was repeated until a $10^{5}$ cells/ $\mathrm{m} \ell$ trophozoite concentration in the culture was obtained. A similar process was conducted to prepare an Acanthamoeba culbertsoni ATCC 30171 suspension used as a reference strain to confirm the identification of amoebae. Faecal coliforms, faecal enterococci and Salmonella Typhi content were measured (Table 1) using the methods proposed in Standard Methods (1998). Acanthamoeba spp. and Acanthamoeba culbertsoni ATCC 30171 were analysed following an ex-cystation technique (Craik et al., 2000) that consists of determining the total quantity of cysts susceptible to be transformed into trophozoites under favourable conditions in a monoxenic culture (in which amoebae are grown in the presence of a single additional species).

\section{Reactivation experiments}

UV-light does not have a residual disinfection effect once the effluent leaves the UV photoreactor. This is a concern because many micro-organisms are able to recover rapidly from the damage caused by the process. Photoreactivation (photo repair) is produced by an enzyme activated with 300 to $500 \mathrm{~nm}$ wavelength energy, which is normally found in water exposed to sunlight. As a consequence, the number of viable bacteria may increase within minutes to hours after disinfection once an effluent is discharged into the environment (Zimmer et al., 2003). This is a cause for concern when treated effluents are not immediately used and are transported in open channels, as frequently happens with treated wastewater reused for irrigation. Under such conditions, it is important to apply a UV dose that can also prevent its reactivation, besides inactivating bacteria. This dose is always higher than the inactivation dose and needs to be determined for each type of micro-organism and effluent. To study photoreactivation, experiments were performed only using bacteria (faecal coliforms and Salmonella Typhi). Since the reactivation rate does not depend on the same physical characteristics of the effluents that are important to the UV-light disinfection efficiency, experiments were carried out using only the activated sludge effluent. For this purpose, a $50 \mathrm{~m} \ell$ sample was disinfected using different UV-light doses. The irradiated effluent was placed in sterile glass bottles and followed by reactivation in both sunlight and darkness conditions for $2 \mathrm{~h}$ (Liltved and Landfald, 2000). Each test was performed twice. The reactivation rate was calculated using Eq. (2) (Lindenauer and Darby, 1994):

$$
\log \frac{N_{r}}{N_{0}}-\log \frac{N}{N_{0}}=\log \frac{N r / N_{0}}{N / N_{0}}=\log \frac{N r}{N}
$$

where:

$$
\begin{aligned}
& N_{0}= \begin{array}{l}
\text { Micro-organism concentration before UV irradiation } \\
(\mathrm{CFU} / 100 \mathrm{~m} \ell)
\end{array} \\
& N= \begin{array}{l}
\text { Micro-organism concentration after } \mathrm{UV} \text { irradiation } \\
(\mathrm{CFU} / 100 \mathrm{~m} \ell)
\end{array} \\
& N_{r}=\begin{array}{l}
\text { Micro-organism concentration after reactivation } \\
(\mathrm{CFU} / 100 \mathrm{~m} \ell)
\end{array}
\end{aligned}
$$

The dose reduction factor (DRF) used to predict the increase in the UV inactivation dose to avoid photoreactivation (Lindenauer and Darby, 1994) was calculated using Eq. (3):

$$
\begin{aligned}
& \text { UV dose required for a given log survival after } \\
& \text { DRF }=\frac{\text { UV disinfection without photoreactivation }}{\begin{array}{c}
\text { UV dose required to obtain the same log survival } \\
\text { with photoreactivation }
\end{array}}
\end{aligned}
$$

\section{Effect of embedded micro-organisms on the inactivation efficiency}

The dose-response disinfection curve is specific for each type of micro-organism and effluent (USEPA, 1986). It has 2 regions. A $1^{\text {st }}$ phase, where low UV-light doses inactivate the micro-organisms that are freely suspended in wastewater: this part of the curve is modelled by a first-order kinetics reaction. The $2^{\text {nd }}$ phase of the curve is the tailing region. Under these conditions inactivation is slightly improved although UV-light doses are considerably increased. In this case, doses do not depend on the total number of micro-organisms but on the amount and size of particles, because micro-organisms are embedded in them and their numbers are difficult to determine. To estimate the UV-light dose needed, mathematical models using lumped parameters have been developed (USEPA, 1986). The lumped parameters commonly used are the TSS content, the unfiltered transmittance and the filtered transmittance. Once models are calibrated to a specific effluent, they become useful for designing full-scale UV disinfection facilities.

Experiments to evaluate the effect on the inactivation efficiency of the presence of micro-organisms embedded in particles were carried out using different TSS content as suggested by Andreadakis et al. (1999). The activated sludge effluent was used for these experiments because it had a higher TSS content and it was possible to prepare spiked samples by adding mixed liquor from the aeration tank to the effluent producing different TSS contents (20 to $100 \mathrm{mg} / \ell$ ). Before irradiation, the TSS and the faecal coliform content were determined. The sample was then exposed to different UV-light doses (between 5 and 120 $\mathrm{mW} \cdot \mathrm{s} / \mathrm{cm}^{2}$ ) and then faecal coliform content was once again measured. To calculate the theoretical micro-organism content embedded in particles $(\mathrm{Np})$ in the tailing region, Eq. (4) was used (USEPA, 1986). The TSS and the Np values used for such calculations were the mean values obtained for the different TSS ranges ( 0 to $15 \mathrm{mg} / \ell, 15$ to $30 \mathrm{mg} / \ell, 30$ to $45 \mathrm{mg} / \ell, 45$ to $60 \mathrm{mg} / \ell$ and 60 to $100 \mathrm{mg} / \ell$ ). 


\begin{tabular}{|l|l|l|l|}
\hline \multicolumn{4}{|c|}{ TABLE 2 } \\
\hline Characterisation of secondary effluents \\
\hline & $\begin{array}{l}\text { Activated } \\
\text { sludge } \\
\text { (AS) }\end{array}$ & $\begin{array}{l}\text { Rotating } \\
\text { biological } \\
\text { contactors } \\
\text { (RBC) }\end{array}$ & $\begin{array}{l}\text { Trickling } \\
\text { filter } \\
\text { (TF) }\end{array}$ \\
\hline Total suspended solids, $\mathrm{mg} / \ell$ & $31 \pm 10$ & $9 \pm 2$ & $12 \pm 1$ \\
\hline Transmittance, $\%$ & $55 \pm 7$ & $75 \pm 9$ & $65 \pm 8$ \\
\hline Filtered transmittance, $\%$ & $74 \pm 3$ & $85 \pm 3$ & $79 \pm 3$ \\
\hline Mean particle size, $\mu \mathrm{m}$ & $12 \pm 8$ & $22 \pm 16$ & $19 \pm 13$ \\
\hline Volume of particles $>40 \mu \mathrm{m}, \mathrm{m} \ell / \mathrm{m}^{3}$ & $0.03 \pm 0.02$ & $0.20 \pm 0.10$ & $0.14 \pm 0.12$ \\
\hline Number of particles $>40 \mu \mathrm{m} ; \mathrm{Number} \times 10^{3} / \mathrm{m}^{3}$ & $30 \pm 42$ & $332 \pm 410$ & $280 \pm 474$ \\
\hline
\end{tabular}

$$
N p=c T S S^{m}
$$

where:

$$
\begin{aligned}
N p= & \begin{array}{l}
\text { Micro-organisms embedded in particles } \\
(\mathrm{CFU} / 100 \mathrm{~m} \ell)
\end{array} \\
T S S= & \text { Total suspended solids content }(\mathrm{mg} / \ell) \\
c, m= & \begin{array}{l}
\text { Empirical coefficients specific to each type of } \\
\text { effluent }
\end{array}
\end{aligned}
$$

\section{Risk assessment}

WHO criteria (WHO, 2006) only set values for the faecal coliform content and suggest setting additional values for other micro-organisms depending on the local situation. Therefore, to evaluate the health risks caused by the Salmonella Typhi content of an effluent disinfected in accordance with WHO criteria, the infection probability resulting from exposure $(\mathrm{P})$ was calculated using the beta-Poisson model (Eq. (5), Westrell et al., 2004). The assumptions used for the calculation were: $100 \mathrm{~g}$ portion of lettuce irrigated with treated wastewater; $10 \mathrm{~m} \ell$ volume of wastewater remaining in the product; a $3 \mathrm{log}$ reduction during harvesting and consumption; and a $1 \log$ reduction due to washing (Fattal et al., 2004).

$$
P=1-\left(1+((\mathrm{N} / \beta))^{-\alpha}\right.
$$

where:

$$
\begin{aligned}
P= & \text { Risk of infection per person per consumption of } \\
& 100 \mathrm{~g} \text { of lettuce containing } 10 \mathrm{~m} \ell \text { of treated wastewater } \\
N= & \text { Number of bacteria at the time of consumption } \\
\alpha= & 0.33 \\
\beta= & 139.9
\end{aligned}
$$

The Acanthamoeba spp. risk assessment has not been evaluated due to the lack of data concerning the infective dose and doseresponse relationships. This lack of information is a concern not only for developing countries but also for developed ones, because this micro-organism has been classified as an emergent pathogen by USEPA's CCL (USEPA, 1998).

\section{Results and discussion}

\section{Characterisation of effluents and their effect on UV efficacy}

UV-light efficiency depends not only on the type of microorganisms which require inactivating but also on the effluent's characteristics, such as transmittance, the TSS content and the particle size distribution. In particular, particles shade, reflect or absorb UV-light diminishing its effect on micro-organisms. Also, UV-light efficiency decreases in effluents with TSS contents $>30 \mathrm{mg} / \ell$, transmittance $<60 \%$ and the presence of particles $>40 \mu \mathrm{m}$, according to Madge and Jensen (2006).

The AS effluent came from a suspended growth biological wastewater treatment process and for that reason had the highest TSS content $(31 \pm 10 \mathrm{mg} / \ell)$ and the lowest transmittance value (55 $\pm 7 \%)$, presenting the worst conditions for applying UV-light. In contrast, effluents coming from the attached growth systems, $\mathrm{RBC}$ and TF, presented a lower TSS content (of $9 \pm 2$ and $12 \pm 1$ $\mathrm{mg} / \ell$, respectively) and $20 \%$ higher transmittance values (Table 2). Although the particle size distribution observed for the 3 effluents was different (Fig. 1 and Table 2), the number of particles larger than $40 \mu \mathrm{m}$ (a size that directly affects UV dose) represents a small percentage $(0.12 \%$ on average) in all effluents. In contrast, in terms of volume, particles greater than $40 \mu \mathrm{m}$ were markedly different for the 3 effluents: $2 \%$ of the total volume for the AS effluent $\left(0.03 \mathrm{~m} \ell / \mathrm{m}^{3}\right), 15 \%\left(0.2 \mathrm{ml} / \mathrm{m}^{3}\right)$ for the $\mathrm{RBC}$ one and only $7 \%\left(0.14 \mathrm{m \ell} / \mathrm{m}^{3}\right)$ in the TF one (Fig. 1).

Inactivation efficiencies for each type of micro-organism studied were similar for the 3 effluents using the UV-light dose required to fulfil the WHO criteria $\left(30 \mathrm{~mW} \cdot \mathrm{s} / \mathrm{cm}^{2}\right)$ (Table 3), meaning that differences observed in the TSS content, the trans-

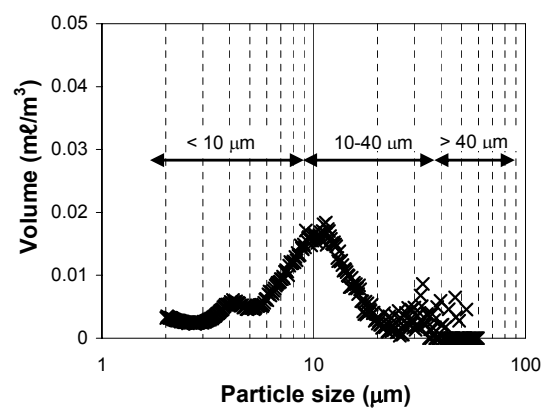

Particle size $(\mu \mathrm{m})$

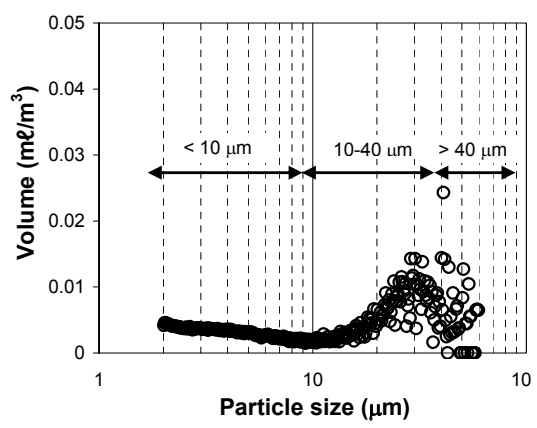

Figure 1

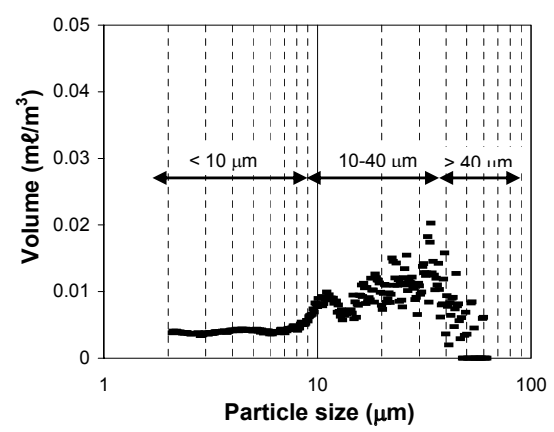

Particle size distribution: (a) activated sludge, (b) rotating biological contactors and (c) trickling filters 


\begin{tabular}{|c|c|c|c|c|c|c|c|c|c|}
\hline \multicolumn{10}{|c|}{$\begin{array}{c}\text { TABLE } 3 \\
\begin{array}{c}\text { Concentration of faecal coliforms, faecal enterococci and Salmonella Typhi for the } \\
\text { three secondary effluents }\end{array}\end{array}$} \\
\hline \multirow{3}{*}{$\begin{array}{c}\text { Dose } \\
\mathrm{mW} \cdot \mathrm{s} / \mathrm{I} \\
\mathrm{cm}^{2}\end{array}$} & \multicolumn{9}{|c|}{$\log (C F U / 100 \mathrm{ml})$} \\
\hline & \multicolumn{3}{|c|}{ Faecal coliforms } & \multicolumn{3}{|c|}{ Faecal enterococci } & \multicolumn{3}{|c|}{ Salmonella Typhi } \\
\hline & AS & RBC & TF & AS & RBC & TF & AS & RBC & TF \\
\hline 0 & $6.2 \pm 0.6$ & $5.6 \pm 0.2$ & $6.0 \pm 0.3$ & $6.5 \pm 0.3$ & $5.5 \pm 0.1$ & $6.0 \pm 0.2$ & $4.8 \pm 0.9$ & $4.2 \pm 0.4$ & $4.5 \pm 0.5$ \\
\hline 5 & $5.5 \pm 0.3$ & $4.8 \pm 0.3$ & $5.3 \pm 0.3$ & $6.0 \pm 0.5$ & $5.3 \pm 0.3$ & $5.8 \pm 0.2$ & $4.1 \pm 0.4$ & $3.1 \pm 0.3$ & $3.4 \pm 0.7$ \\
\hline 10 & $4.1 \pm 0.4$ & $3.9 \pm 0.3$ & $4.0 \pm 0.5$ & $5.4 \pm 0.4$ & $4.9 \pm 0.3$ & $4.9 \pm 0.3$ & $3.2 \pm 0.4$ & $2.6 \pm 0.4$ & $2.9 \pm 0.8$ \\
\hline 15 & $2.9 \pm 0.3$ & $2.9 \pm 0.3$ & $3.2 \pm 0.4$ & $4.5 \pm 0.3$ & $3.7 \pm 0.5$ & $4.0 \pm 0.5$ & $2.6 \pm 0.7$ & $1.9 \pm 0.5$ & $2.2 \pm 0.4$ \\
\hline 30 & $2.4 \pm 0.3$ & $2.5 \pm 0.4$ & $2.3 \pm 0.6$ & $3.1 \pm 0.4$ & $3.2 \pm 0.3$ & $3.2 \pm 0.5$ & $1.7 \pm 0.5$ & $1.8 \pm 0.5$ & $1.5 \pm 0.8$ \\
\hline 60 & $1.8 \pm 0.2$ & $2.0 \pm 0.3$ & $1.9 \pm 0.3$ & $2.1 \pm 0.9$ & $2.7 \pm 0.3$ & $2.7 \pm 0.6$ & $1.1 \pm 0.7$ & $0.4 \pm 0.7$ & $1.2 \pm 0.8$ \\
\hline 120 & $0.7 \pm 0.6$ & $1.1 \pm 0.9$ & $1.3 \pm 0.6$ & $0.9 \pm 0.9$ & $2.3 \pm 0.4$ & $2.0 \pm 0.3$ & 0.0 (NA) & $0.1 \pm 0.4$ & $0.3 \pm 0.5$ \\
\hline
\end{tabular}

mittance values and the particle size distribution were not determinants in the 3 biological effluents. This was explained by the fact that they came from the same influent and had a low number of particles over $40 \mu \mathrm{m}$ in size. Although the RBC and the TF effluent distribution curves had greater volumes of particles over $40 \mu \mathrm{m}$, this did not seem to affect the UV-light dose.

The UV dose-response curves (Fig. 2) show the typical inactivation phases. In the $1^{\text {st }}$ phase (for doses $<15 \mathrm{~mW} \cdot \mathrm{s} / \mathrm{cm}^{2}$ ) the inactivation of free micro-organisms not associated with particles followed a first-order reaction. The $2^{\text {nd }}$ phase (tailing of the curve) was observed for UV-light doses $>30 \mathrm{~mW} \cdot \mathrm{s} / \mathrm{cm}^{2}$.

\section{Effects of WHO criteria UV dose on bacteria and amoebae}

For all effluents, the $30 \mathrm{~mW} \cdot \mathrm{s} / \mathrm{cm}^{2}$ dose inactivated $3 \log$ of faecal coliforms fulfilling the WHO criteria for agricultural irrigation and $1000 \mathrm{MPN} / 100 \mathrm{~m} \ell$ (Table 3). This dose is similar to the one reported by Jacangelo et al. (2003) of 30 to $45 \mathrm{~mW} \cdot \mathrm{s} / \mathrm{cm}^{2}$ to inactivate $3 \log$ of faecal coliforms in secondary effluents. Faecal enterococci, not considered in the WHO criteria or in the Mexican standard, showed a higher resistance than faecal coliforms in the $1^{\text {st }}$ phase of the doseresponse curve, because it was inactivated by only 2 logs. This behaviour was attributed to the ability of some micro-organisms to absorb sub-lethal irradiation doses without displaying any adverse effect measurable through the analytical techniques used to quantify their viability (Task Force on Wastewater Disinfection, 1996). Concerning Salmonella Typhi, it was inactivated to concentrations of below the human infective dose $\left(10^{3}\right)$ by applying only $15 \mathrm{~mW} \cdot \mathrm{s} / \mathrm{cm}^{2}$. The total $\log$ reduction achieved for this pathogen when fulfilling the WHO criteria was $3 \log$ units. With the $30 \mathrm{~mW} \cdot \mathrm{s} / \mathrm{cm}^{2}$ dose Acanthamoeba spp. was not affected at all. A $2 \log$ reduction was observed until a $40 \mathrm{~mW} \cdot \mathrm{s} / \mathrm{cm}^{2}$ dose was reached, i.e. two times greater than the one required to inactivate $E$. coli (Chang et al., 1985). Total inactivation of Acanthamoeba spp. was reached with doses of up to $173 \mathrm{~mW} \cdot \mathrm{s} / \mathrm{cm}^{2}$, confirming its high resistance to disinfection as frequently reported for other protozoan but also indicating that the low doses recommended for Cryptosporidium (2 to $3 \mathrm{~mW} \cdot \mathrm{s} / \mathrm{cm}^{2}$ ) (Linden et al.,
2001) certainly do not apply in the case of this micro-organism. In the literature, no doses for inactivating Acanthamoeba spp. have been reported to compare with, but for Acanthamoeba castellanii a much higher dose, of $800 \mathrm{~mW} \cdot \mathrm{s} / \mathrm{cm}^{2}$ (Aksozek et al., 2002), has been reported. Using other disinfection methods, Acanthamoeba spp. has been inactivated with $3 \mathrm{mg} \mathrm{ClO} / \ell$ and $7 \mathrm{mg} \mathrm{O} / \ell$, which are doses 10 and 70 times greater that those needed to inactivate bacteria, respectively (Cursons et al., 1980; Dawson and Brown, 1987). It should be noticed that the Acanthamoeba content used in the study was much higher $\left(10^{4}\right.$ cysts $\left./ \mathrm{m} \ell\right)$ than the one that might be present in wastewater. Usual content of other types of protozoan, such as Giardia Cryptosporidium or Entamoeba coli and histolytica are lower in wastewater $\left(10^{2}\right.$ to $10^{6}, 10^{1}$ to $10^{4}, 10^{2}$ cysts/ $\ell$ respectively; Cacciò et al., 2003; Lonigro et al., 2006). So it can be assumed that the actual content of Acanthamoeba in wastewater could be inactivated with lower doses.

\section{Kinetics parameter}

To measure the micro-organisms' sensitivity to UV-light irradiation, the inactivation rate constant was determined using a first-
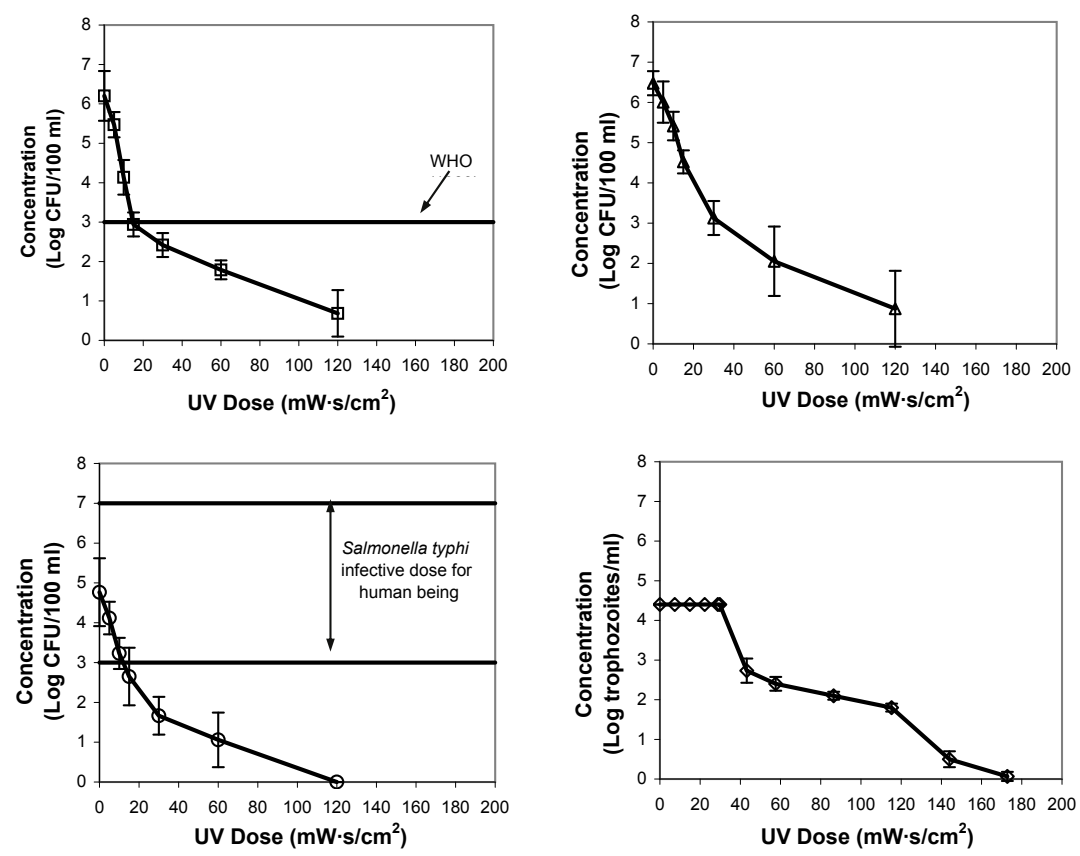

Figure 2

Dose-response curves: ( $\square$ ) faecal coliforms, $(\Delta)$ faecal enterococci and (O) Salmonella Typhi and $(\diamond)$ Acanthamoeba spp. in an activated sludge effluent 


\begin{tabular}{|l|c|c|c|c|}
\hline \multicolumn{5}{|c|}{ TABLE 4 } \\
UV inactivation rate constants of faecal coliforms, faecal enterococci, \\
Salmonella Typhi and Acanthamoeba spp. for three secondary effluents
\end{tabular}

order equation. Inactivation rate constants (Table 4) showed that the most sensitive micro-organisms were $\mathrm{FC}\left(0.48 \mathrm{~cm}^{2} / \mathrm{mW} \cdot \mathrm{s}\right)$, although it is considered the universal indicator. The inactivation rate values obtained in this study for faecal coliforms and enterococci were similar to those reported by Moreland et al. (1998), of 0.34 and $0.28 \mathrm{~cm}^{2} / \mathrm{mW} \cdot \mathrm{s}$ respectively, also using secondary effluents. In contrast, Salmonella Typhi inactivation rate values reported in the literature are greater $\left(0.92\right.$ y $\left.1.1 \mathrm{~cm}^{2} / \mathrm{mW} \cdot \mathrm{s}\right)$ (Task Force on Wastewater Disinfection, 1996) than the value obtained in this research. This difference may be due to the greater resistance of indigenous strains compared to pure strains. This should be considered when using results obtained from the literature in ideal conditions to model local conditions.

Even though the Salmonella Typhi inactivation rate was slower than the one for faecal coliforms, the use of these bacteria as an indicator of the former is feasible because Salmonella Typhi is always present in lower concentrations in wastewater (usually 2 to $6 \log$ less) which is not the case with faecal enterococci which are present in similar densities to faecal coliforms ( $10^{4}$ to $10^{7}$ and $10^{6}$ to $10^{8}$, respectively) (Tchobanoglous et al., 2003).

Acanthamoeba spp., as expected, was the most resistant micro-organism in this study, with an inactivation constant rate of $0.05 \mathrm{~cm}^{2} / \mathrm{mW} \cdot \mathrm{s}$. Its resistance is due to its cyst wall composed of a phosphoprotein layer (external) and a cellulose layer (internal) that acts as an extracellular barrier (Marciano-Cabral and Cabral, 2003). This chemically and structurally complex cell wall gives the structure opacity, protecting its genetic material from UV-light (Maya et al., 2003). Acanthamoeba spp. low inactivation suggests again the need to use additional microbial indicators when wastewater containing different types of pathogens, such as protozoan, are involved.

Since cysts are 15 times more resistant than vegetative bacteria, faecal coliforms may not serve as reliable quantitative models for disinfecting cysts, according to Chang et al. (1985). Thus it would be convenient not only to perform disinfection tests under laboratory conditions to define the sensitivity of different pathogens and to determine the doses needed, but also to monitor full-scale processes using indicators at adequate concentrations. With respect to bacteria, results showed the limited application of faecal coliforms as indicators and suggested the usefulness of replacing them in some justified cases such as faecal pollution indicators by faecal enterococci. The analytical procedures used to determine them are similar but the costs differ (21 USD and 32 USD for faecal coliform and faecal enterococci, respectively, USEPA, 2001) for the former being lower.

\section{Reactivation}

Faecal coliform content increased by 1.4 logs in sunlightexposed samples treated with $30 \mathrm{~mW} \cdot \mathrm{s} / \mathrm{cm}^{2}$, exceeding criteria and standard limits for agricultural reuse in $120 \mathrm{~min}$. Observed photoreactivation capacity for Salmonella Typhi was less than that observed for faecal coliforms. Even though they increased by a maximum of $1.9 \operatorname{logs}$ with the $30 \mathrm{~mW} \cdot \mathrm{s} / \mathrm{cm}^{2}$ dose, the content did not reach the infective dose $\left(10^{3}\right)$. Photoreactivation was not observed for any of the bacteria followed when doses greater than $60 \mathrm{~mW} \cdot \mathrm{s} / \mathrm{cm}^{2}$ were applied (Fig. 3). Similar results have been reported by Lindenauer and Darby (1994).

When samples were kept in the dark, a slight reactivation was observed only for faecal coliforms. Dark repair mechanism (a multi-enzymatic mechanism termed excision repair) for both faecal coliforms and Salmonella Typhi, was not effective even for low UV doses. The maximum growth observed in these conditions was around $0.3 \log$ for all the doses applied.

The reduction dose factor for faecal coliforms calculated using Eq. (3) was 0.5, meaning that the recommended dose for disinfection and avoiding reactivation needs to be at least $60 \mathrm{~mW} \cdot \mathrm{s} / \mathrm{cm}^{2}$. However, it must be borne in mind that photoreactivation rates determined in the laboratory very often represent maximum reactivation rates since other variables such as energy, death, predation and temperature present in field conditions are not involved. Thus, in field conditions photoreactivation will be less frequent (Whitby and Palmateer, 1993).

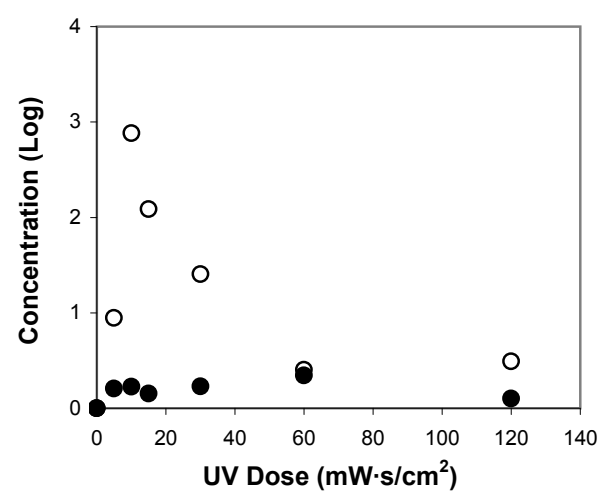

(a)

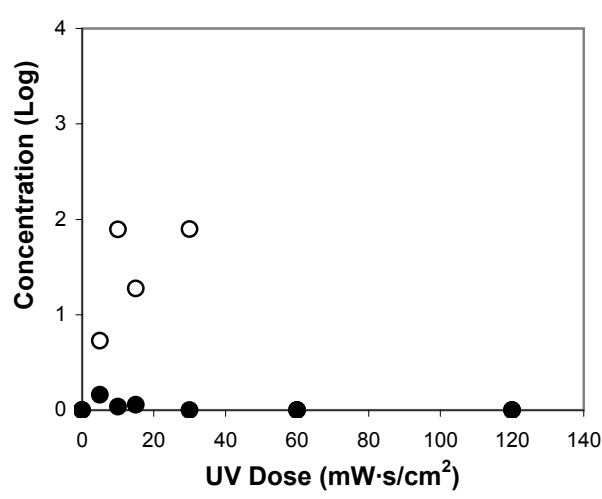

(b) 


\section{Effect of embedded micro-organisms on inactivation efficiency}

Samples prepared adding TSS to the AS effluent displayed similar faecal coliform concentrations (around $7 \pm 0.3 \mathrm{log}$ ) even though the TSS content varied from 5 to $100 \mathrm{mg} / \ell$, due to the analytical technique used to measure bacteria which cannot differentiate among bacteria embedded in flocs. The UV-light dose-response curves for the different TSS contents (Fig. 4) showed the typical behaviour, with first-order inactivation and tailing regions. All the dose-response curves obtained had similar slopes $(0.217$ \pm 0.04 ) indicating that the inactivation of free micro-organisms was carried out independently of the SS content. All said, the disinfection efficiency diminished as the TSS increased in the tailing region only.

However, in the tailing region, as the SS concentration increased, the inactivation rates diminished from 0.19 to 0.03 $\mathrm{cm}^{2} / \mathrm{mW} \cdot \mathrm{s}$ for TSS between 15 and $100 \mathrm{mg}$ TSS/ $\ell$. For TSS contents higher than $30 \mathrm{mg} / \ell$, the inactivation rate for the tailing region remained constant and equal to $0.02 \mathrm{~cm}^{2} / \mathrm{mW} \cdot \mathrm{s}$, even when using the higher UV-light doses (Table 5). These results support the idea that better UV-light disinfection efficiencies and consequently lower costs may be achieved in effluents with less than $30 \mathrm{mg} \mathrm{TSS} / \ell$. Thus, it is recommended that particles be physically removed (i.e. filtration) when higher TSS contents are involved (Loge et al., 2002).

The values found for constants $\mathrm{c}$ and $\mathrm{m}$ with a correlation coefficient of 0.8 were 0.06 and 2.42 , respectively. They differ notably from those proposed by USEPA (1986) of $\mathrm{c}=0.26$ and $\mathrm{m}=1.9$ that are commonly used when no empirical information is available. Therefore it is important to determine these values in practice. At higher UV doses where most of the free bacteria have been inactivated, the residual bacteria density should be close to Np. Equation (6) is based on values obtained from Eq.(4), to evaluate the minimum faecal coliform content that may be achieved with a UV-light process at different TSS content.

$$
N_{p}=0.06 T_{S S}^{2.42}
$$

\section{Infectious risk assessment}

Because it was observed that after fulfilling the WHO criteria Salmonella Typhi was still present, the infection risk was estimated. This was performed using the final concentration for samples treated with 30 and $60 \mathrm{~mW} \cdot \mathrm{s} / \mathrm{cm}^{2}$ (WHO criteria and optimal UV dose determined according to results), and considering a single consumption of $100 \mathrm{~g}$ of irrigated lettuce containing $10 \mathrm{~m} \ell$ of treated effluent, a 3-log die-off between irrigation and consumption and using the $\beta$-Poisson model (Eq. (7)). Parameters used in this equation were those recommended by Rose and Gerba (1991).

$$
P_{I}=1-\left(1+\frac{N}{139.9}\right)^{-0.33}
$$

The infection risk value for Salmonella Typhi turned out to be $\mathrm{P}_{\mathrm{I}}=1.2 \times 10^{-5}$ for $30 \mathrm{~mW} \cdot \mathrm{s} / \mathrm{cm}^{2}$ and of $\mathrm{P}_{\mathrm{I}}=3.1 \times 10^{-6}$ for 60 $\mathrm{mW} \cdot \mathrm{s} / \mathrm{cm}^{2}$, which are acceptable according to the USEPA criteria (USEPA, 1992), which establishes a limit of $\mathrm{P}_{\mathrm{I}}=10^{-4}$. For comparison purposes, the annual infection risk caused by salmonella when consuming $100 \mathrm{~g}$ of lettuce irrigated with raw wastewater varies from $1.5 \times 10^{-1}$ to $5 \times 10^{-2}$, meaning that 5 to $15 \%$ of the consumers are at risk of getting the disease (Fattal et al., 2004).

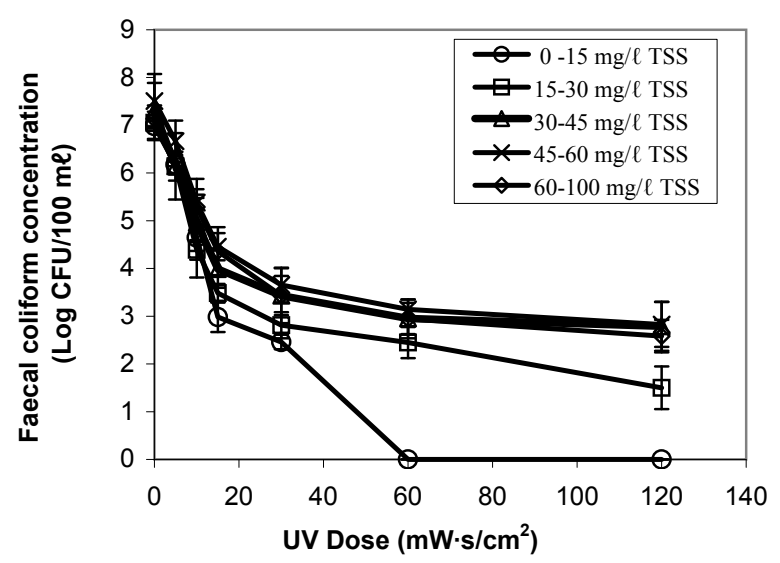

Figure 4

Effect of total suspended solids concentration on faecal coliforms' dose response

\begin{tabular}{|c|c|c|}
\hline \multicolumn{3}{|c|}{ TABLE 5 } \\
\multicolumn{2}{|c|}{$\begin{array}{c}\text { Faecal coliform inactivation rate } \\
\text { constants for the tailing region }\end{array}$} \\
\hline $\begin{array}{c}\text { Total suspended } \\
\text { solids concentration } \\
\text { (mg/e) }\end{array}$ & $\begin{array}{c}\mathbf{k} \\
(\mathbf{c m} / \mathbf{m W} \cdot \mathbf{s})\end{array}$ & $\mathbf{R}^{\mathbf{2}}$ \\
\hline $0-15$ & 0.19 & 1.00 \\
\hline $15-30$ & 0.03 & 1.00 \\
\hline $30-45$ & 0.02 & 0.80 \\
\hline $45-60$ & 0.02 & 0.90 \\
\hline $60-100$ & 0.02 & 0.93 \\
\hline
\end{tabular}

\section{Conclusions}

A dose of $30 \mathrm{~mW} \cdot \mathrm{s} / \mathrm{cm}^{2}$ is enough to fulfil WHO criteria and to inactivate $3 \log$ Salmonella Typhi and faecal enterococci in the three different effluents (AS, RBC and TF) coming from the same influent, even though the TSS content and the particle size distribution were different. This was explained by the amount of particles $>40 \mu \mathrm{m}$ in the 3 effluents being low. For any of the effluents, the disinfection efficiency is affected by the presence of micro-organisms embedded in particles. No Acanthamoeba inactivation was observed at $30 \mathrm{~mW} \cdot \mathrm{s} / \mathrm{cm}^{2}$; however, a $2.5 \mathrm{log}$ reduction of Acanthamoeba as well as an average of $4 \log$ for bacteria (faecal coliform, faecal enterococci and Salmonella Typhi) is reached when applying the recommended UV-light dose to fulfil the WHO criteria and to avoid photoreactivation $\left(60 \mathrm{~mW} \cdot \mathrm{s} / \mathrm{cm}^{2}\right)$. However, if it is necessary to fully inactivate it, this dose would need to be tripled and UV disinfection may turn into an economically nonviable process. Since Acanthamoeba trophozoites and cysts are relatively large, physical treatment processes such as flocculation, sedimentation and filtration can be effective in their removal.

The mean inactivation rate constants calculated in the linear region of the disinfection curves for the 3 effluents $\left(0.4 \mathrm{~cm}^{2} / \mathrm{mW} \cdot \mathrm{s}\right.$ for faecal coliforms, $0.26 \mathrm{~cm}^{2} / \mathrm{mW} \cdot \mathrm{s}$ for faecal enterococci, $0.37 \mathrm{~cm}^{2} / \mathrm{mW} \cdot \mathrm{s}$ for Salmonella Typhi and 0.05 $\mathrm{cm}^{2} / \mathrm{mW} \cdot \mathrm{s}$ for Acanthamoeba spp.) showed that the most sensitive micro-organisms were faecal coliforms, although these are generally considered the usual indicator. Considering the resistance of faecal enterococci, their use as an indicator besides faecal coliforms, should be evaluated. Also, since there is minimal to no correlation between bacterial indicators and protozoa, the use of other types of indicators, particularly in developing countries, should also be considered. 
The health risks produced by effluents disinfected with $30 \mathrm{~mW} \cdot \mathrm{s} / \mathrm{cm}^{2}$ and $60 \mathrm{~mW} \cdot \mathrm{s} / \mathrm{cm}^{2}$ are between 0.0003 and $0.001 \%$ for Salmonella Typhi, which is acceptable. However, even though the risk assessment for Acanthamoeba spp. could not be quantified because of a lack of information, the probability of infection still exists. Even though it is rarely possible, and generally quite unnecessary, to use sterile or pathogen-free water for irrigation, it is suggested that biological parameters other than conventional indicators be considered during experimental studies to perform the design of UV-light facilities in order to safely reuse wastewater for agriculture in developing countries. As a result, public health may be protected without increasing routine monitoring costs, particularly in several regions from the developing world where wastewater is reused.

\section{Acknowledgements}

The authors wish to thank Trojan Technologies, INC for its technical support and partial funding for this project.

\section{References}

ADIN A (1998) Physicochemical mechanisms in treatment processes for water reuse. In: Asano $\mathrm{T}$ (ed.) Wastewater Reclamation and Reuse. Technomic Publishing Co. Inc, USA.

AKSOZEK A, McCLELLAN K, HOWARD K, NIEDERKORN J and ALIZADEH H (2002) Resistance of Acanthamoeba castellanii cysts to physical, chemical and radiological conditions. J. Parasitol. 88 (3) $621-623$.

ANDREADAKIS A, MAMAIS D, CHRISTOULAS D and KABYLAFKA S (1999) Ultraviolet disinfection of secondary and tertiary effluents in the Mediterranean region. Water Sci. Technol. 40 (4/5) 253-260.

ASHBOLT N, GRABOW W and SNOZZI M (2001) Indicators of microbial water quality. In: Fewtrell L and Bartram J (eds.) Water Quality: Guidelines, Standards and Health. IWA Publishers, London, UK.

CACCIÒ S, DE GIACOMO M, AULICINO F and POZIO E (2003) Giardia cysts in wastewater treatment plants in Italy. Appl. Environ. Microbiol. 69 (6) 3393-3398.

CARR R, BLUMENTHAL U and MARA D (2004) Health guidelines for the use of wastewater in agriculture: Developing realistic guidelines. In: Scott C, Faruqui N and Raschid L (eds.) Wastewater Use in Irrigated Agriculture. Confronting the Livelihood and Environmental Realities. CABI/IWMI/IDRC: Wallingford, UK. 240 pp.

CDC (2001) Centers for Disease Control and Prevention. Typhoid fever http://www.cdc.gov/ncidod/dbmd/diseaseinfo/files/typhoid fever FAQ.pdf.

CHANG J, OSSOFF S, LOBE D, DORFMAN M, DUMAIS C, QUALLS $\mathrm{R}$ and JOHNSON J (1985) UV Inactivation of pathogenic and indicators microorganisms. Appl. Environ. Microbiol. 49 (6) 1361-1365.

CRAIK S, FINCH G, BOLTON J and BELOSEVIC M (2000) Inactivation of Giardia muris cysts using medium-pressure ultraviolet radiation in filtered drinking water. Water Res. 34 (18) 4325-4332.

CURSONS R, BROWN T and KEYS E (1980) Effect of disinfectants on pathogenic free-living amoebae in axenic conditions. Appl. Environ. Microbiol. 40 (1) 62-66.

DAWSON M and BROWN T (1987) The effect of chlorine and chlorine dioxide on pathogenic free-living amoebae (PFLA) in simulated natural conditions: the presence of bacteria and organic matter. N. Z. J. Mar. Fresh. 21 117-123.

DODDS L, KING W, WOOLCOTT C and POLE J (1999) Trihalomethanes in public water supplies and adverse birth outcomes. Epidemiol. 10 (3) 33-237.

DREELIN E (2005) Waterborne Microbial Pathogens in the Great Lakes. Report prepared for the International Joint Commission. Great Lakes Regional Office, International Joint Commission, Windsor, Ontario.

FATTAL B, LAMPERT Y and SHUVAL H (2004) A fresh look at microbial guidelines for wastewater irrigation in agriculture: A risk- assessment and cost-effectiveness approach. In: Scott C, Faruqui N and Raschid L (eds.) Wastewater Use in Irrigated Agriculture. Confronting the Livelihood and Environmental Realities. CABI/IWMI/ IDRC: Wallingford, UK. 240 pp.

FOSTER S, GARDUÑO H, TUINHOF A, KEMPER K and NANNI M (2003) Urban Wastewater as Groundwater: Evaluating and Managing the Risks and Benefits. GW MATE Briefing Note Series No. 12; World Bank: Washington, DC.

HINRICHSEN D and ROBEY B (2000) Population and the Environment: The Global Challenge. Population Reports. Series M, No. 15. Population Information Program, Johns Hopkins University Schoo of Public Health; and United Nations Environment Programme: Baltimore, MD.

JACANGELO J, LOUGHRAN P, PETRIK B, SIMPSON D and McLLROY C (2003) Removal of enteric viruses and selected microbial indicators by UV radiation of secondary effluent. Water Sci. Technol. 47 (9) 193-198.

JIJNEN W, BEERENDONK E and MEDEMA G (2006) Inactivation credit of UV radiation for viruses, bacteria and protozoa (oo)cysts in water: a review. Water Res. 40 (1) 3-22.

JIMÉNEZ B, CHÁVEZ A, MAYA C and JARDINES L (2001) Removal of microorganisms in different stages of wastewater treatment from Mexico City. Water Sci. Technol. 43 (10) 155-162.

JIMÉNEZ B and CHÁVEZ A (2004) Quality assessment of an aquifer recharge with wastewater for its potential use as drinking source: 'El Mezquital Valley' case. Water Sci. Technol. 50 (2) 269-276.

LINDEN K, SHIN G, FAUBERT G, CAIRNS W and SOBSEY M (2002) UV disinfection of Giardia lamblia cysts in water. Environ. Sci. Technol. 36 (11) 2519-2522.

LINDEN K, SHIN G and SOBSEY M (2001) Comparative effectiveness of UV wavelengths for the inactivation of Cryptosporidium parvum oocysts in water. Water Sci. Technol. 43 (12) 171-174.

LINDENAUER K and DARBY J (1994) Ultraviolet disinfection of wastewater effect of dose on subsequent photoreactivation. Water Res. 28 (4) 805-817.

LILTVED H and LANDFALD B (2000) Effects of high intensity light on ultraviolet-irradiated and non-irradiated fish pathogenic bacteria. Water Res. 34 (2) 481-486.

LOGE F, EMERICK R, GINN T and DARBY J (2002) Association of coliform bacteria with wastewater particles: Impact of operational parameters of the inactivated sludge process. Water Res. 36 (1) 41-48.

LONIGRO A, POLLICE A, SPINELLI R, BERRILLI F, DI CAVE D, D'ORAZI C, CAVALLO P and BRANDONISIO O (2006) Giardia cysts and Cryptosporidium oocysts in membrane-filtered municipal wastewater used for irrigation. Appl. Environ. Microbiol. 72 (12) 7916-7918.

MADGE B and JENSEN J (2006) Ultraviolet disinfection of faecal coliform in municipal wastewater: effects of particle size. Water Environ. Res. 78 (3) 294-304.

MARCIANO-CABRAL F and CABRAL G (2003) Acanthamoeba spp. as agents of disease in humans. Clin. Microbiol. Rev. 16 (2) 273-307.

MARTÍNEZ AJ and VISVESVARA GS (1997) Free-living, amphizoic and opportunistic amebas. Brain Pathol. 7 (1) 583-589.

MAYA C (2000) M.Sc. thesis. National Autonomous University of Mexico (UNAM). México D.F. México (In Spanish).

MAYA C, BELTRÁN N, JIMÉNEZ B and BONILLA P (2003) Evaluation of the UV disinfection process in bacteria and amphizoic amoebae inactivation. Water Sci. Technol.: Water Supply 3 (4) 285-291.

MORELAND V, ASAHINA A, UNUTOA T and FUJIOKA R (1998) UV disinfection to pilot or not to pilot? Water Environ. Technol. 10 (6) 47-51.

NORHAYATI M, FATMAH M, YUSOF S and EDARIAH A (2003) Intestinal parasitic infections in man: A review. Med. J. Malaysia 58 (2) 296-305.

ROSE JB and GERBA CP (1991) Use of risk assessment for development of microbial standards. Water Sci. Technol. 24 (2) 29-34.

SCOTT C, FARUQUI N and RASHID-SALLY L (2004) Wastewater use in irrigated agriculture: management challenges in developing countries. In: Scott C, Faruqui N and Raschid L (eds.) Wastewater Use in Irrigated Agriculture. Confronting the Livelihood and Envi- 
ronmental Realities. CABI/IWMI/IDRC: Wallingford, UK. 240 pp. STANDARD METHODS (1998) Standard Methods for the Examination of Water and Wastewater (20 ${ }^{\text {th }}$ edn.). American Public Health Association/American Water Works Association/Water Environment Federation. Washington, DC.

TASK FORCE ON WASTEWATER DISINFECTION (1996) Wastewater Disinfection, Manual of Practice. FD; No. 10. Water Environment Federation (WEF): Alexandria, VA.

TCHOBANOGLOUS G, BURTON F and STENSEL D (2003) Wastewater Engineering: Treatment and Reuse (4th edn.). Metcalf and Eddy Inc. McGraw-Hill, New York, N.Y.

USEPA (1986) Design Manual: Municipal Wastewater Disinfection. United States Environmental Protection Agency. Manual EPA/625/1-86/021. Office or Research and M Development, Water Engineering Research Laboratory: Cincinnati, $\mathrm{OH}$.

USEPA (1998) Announcement of the drinking water contaminant candidate list. United States Environmental Protection Agency. Federal Register 63 Notices.

USEPA (1992) Guidelines for Water Reuse. United States Environmental Protection Agency. Manual EPA/625/R-92/004; Office of Water, EPA: Washington, D.C.
USEPA (2001) Guidelines Establishing Test Procedures for the Analysis of Pollutants; Analytical Methods for Biological Pollutants in Ambient Water; Proposed Rule. http://www.epa.gov/fedrgstr/EPAWATER/2001/August/Day-30/w21813.htm

WESTRELL T, SCHONNING C, STENSTROM T and ASHBOLT N (2004) QMRA (Quantitative Microbial Risk Assessment) and HACCP (Hazard Analysis and Critical Control Points) for management of pathogens in wastewater and sewage sludge treatment and reuse. Water Sci. Technol. 50 (2) 23-30.

WHITBY G and PALMATEER G (1993) The effect of UV transmission, suspended solids and photoreactivation on microorganisms in wastewater treated with UV light. Water Sci. Technol. 27 (3/4) 379-386.

WHO (1998) Typhoid Fever. Fact Sheet N149 World Health Organization: Geneva. http://www.who.int/inf-fs/en/fact149.htm

WHO (2006) Guidelines for the safe use of wastewater, excreta and greywater. Volume II. Wastewater use in agriculture. $196 \mathrm{pp}$.

ZIMMER J, SLAWSON R and HUCK P (2003) Inactivation and potential repair of Cryptosporidium parvum following low- and mediumpressure ultraviolet irradiation. Water Res. 37 (14) 3517-3523. 
Available on website http://www.wrc.org.za ISSN 0378-4738 = Water SA Vol. 34 No. 2 April 2008

ISSN 1816-7950 = Water SA (on-line) 